Łucja Farnik

\title{
Księdza profesora Kazimierza Waisa propozycja zharmonizowania nauki i wiary w kwestii pochodzenia człowieka
}

Niniejszy artykuł ma na celu zaprezentowanie prób, jakie podejmował ksiądz profesor Kazimierz Wais, aby ukazać niesprzeczność nauki i wiary w kwestii pochodzenia człowieka.

Ks. Kazimierz Wais ${ }^{1}$ (1865-1934) był polskim filozofem i teologiem, prekursorem na ziemiach polskich myśli neotomistycznej, uprawianej w duchu lowańskim. W swoich pracach podejmował zagadnienia dotyczące zarówno przyrody organicznej jak i nieorganicznej, rozpatrywał, czy dla powstania nowych form życia konieczne było działanie Boga, rozważał możliwości interpretacji fragmentów Pisma Świętego, związanych z kwestiami przyrodniczymi, zajmował się także psychologią, a szczególnie tematem duszy ludzkiej.

\footnotetext{
${ }^{1}$ Szczegółową biografię Waisa można znaleźć na przykład w: J. Stepa, „Ks. Kazimierz Wais (1865-1934)”, Przeglad Filozoficzny, 37, z. 3 (1934), s. 303-306; w: A. Gerstmann, S. Momidłowski, J. Stepa, „Życie i działalność śp. ks. Kazimierza Waisa”, Collectanea Theologica, 16, z. 1 (1935), s. 1-21 oraz w: W. Gretka, „Wais Kazimierz”, [w:] Powszechna Encyklopedia Filozofii, t. 9, A. Maryniarczyk (red.), Polskie Towarzystwo Tomasza z Akwinu, Lublin 2008, dostępne także online: < http://www.ptta.pl/pef/pdf/w/wais_k.pdf>, 25.10.2010.
} 
Ks. Wais był profesorem teologii fundamentalnej i filozofii chrześcijańskiej na Wydziale Teologicznym Uniwersytetu im. Jana Kazimierza we Lwowie. Na poczattku XX wieku teologia fundamentalna zajmowała się głównie apologetyką ${ }^{2}$, zaś „obowiązującą" filozofią chrześcijańską była neoscholastyka utożsamiana z neotomizmem $^{3}$. Liczne publikacje ${ }^{4}$ i odczyty naukowe Waisa wpisywały się w te dwa nurty ${ }^{5}$ - na gruncie ewolucjonizmu próbował on, jako filozof i teolog, harmonizować naukę i wiarę, walcząc w ten sposób z rozpowszechnianymi wówczas antyreligijnymi poglądami materialistycznymi. Rozwiązania przyjęte przez Waisa odegrały ważną historycznie rolę, gdyż za sprawą jego podręcznika Kosmologia szczególowa (1931-1932) stały się podstawą nauczania filozofii przyrody w seminariach duchownych przez kilka następnych dziesięcioleci.

2Zob. „Teologia fundamentalna” oraz „Apologetyka”, [w:] H. Vorgrimler, Nowy leksykon teologiczny, Verbinum, Warszawa 2005.

Obecnie przyjmuje się, że zadaniem teologii fundamentalnej jest systematyzacja faktów teologicznych i ich egzystencjalna analiza. Zob. J. Majka, Metodologia nauk teologicznych, wyd. Wrocławskiej Księgarni Archidiecezjalnej, Wrocław 1981, s. 253.

${ }^{3} \mathrm{~W}$ związku z szerzącym się w Europie w II połowie XIX wieku pozytywizmem i modernizmem powracano do tomizmu jako narzędzia, które odnowi myśl filozoficzną i teologiczną. Inicjatywa ta znalazła poparcie w encyklice Leona XIII Aeterni Patris (1879), w której papież zalecił, by filozofię i teologię uprawiać ad mentem sancti Thomae, to jest w duchu św. Tomasza. Zob. Leon XIII, encyklika Aeterni Patris. O filozofii chrześcijańskiej (4 VII 1879), Te Deum, Warszawa 2003.

${ }^{4}$ Pisma Waisa zostały zestawione w artykule: J. Wołczański, „Życiorys i bibliografia opublikowanych prac ks. prof. dra Kazimierza Waisa za lata 1895-1932", Roczniki Filozoficzne, t. XXXI, z. 1 (1983), s. 133-145. Podana przez ks. prof. Wołczańskiego lista publikacji Waisa jest imponująca - zawiera 104 pozycje (w tym 12 haseł encyklopedycznych) oraz 2 prace redakcyjne.

${ }^{5} \mathrm{~W}$ opracowaniu „Apologetyka polska” można przeczytać, że „Wais był pierwszoplanową postacią w konfrontacji katolicyzmu z przeciwnikami ideologicznymi tego okresu”, a podejmowana przez niego problematyka „ujmowana była wyraźnie w duchu filozofii neoscholastycznej”. Zob. S. Nagy, „Apologetyka polska", [w:] Dzieje teologii katolickiej w Polsce, t. 3, cz. 1, Lublin 1976, s. 201. 
Z racji wyboru tematu, niniejszy artykuł ma charakter historyczny i ma na celu przybliżyć zapomniany rozdział z dziejów polskiej myśli filozoficznej i teologicznej.

We wszystkich cytatach zachowano oryginalną pisownię. Tam, gdzie Wais niekonsekwentnie stosował wielką literę ${ }^{6}$, pisownia została ujednolicona według obecnych standardów. W cytatach uwspółcześniono pisownię skrótów ${ }^{7}$. Wszystkie wyróżnienia w tekstach źródłowych zostały zachowane - zastosowano pogrubioną czcionkę.

\section{Zarys kontekstu historycznego}

Pisma ewolucyjne Waisa wyraźnie koncentrują się wokół trzech tematów: powstania życia, pochodzenia gatunków oraz pochodzenia człowieka ${ }^{8}$. Przyjrzyjmy się, z jakich powodów wątki te były szczególnie istotne dla filozofii przyrody i teologii początku XX wieku.

Od publikacji dzieł K. Darwina O pochodzeniu gatunków (1859) oraz $O$ pochodzeniu cztowieka (1871) kwestie ewolucyjne były aktualnymi tematami ${ }^{9}$, zarówno w środowiskach uniwersyteckich

\footnotetext{
${ }^{6} \mathrm{Na}$ przykład termin „darwinizm” napisany jest małą literą w pozycji: K. Wais, „Dodatek I. O początku rodu ludzkiego”, [w:] Psychologia, t. IV, Skład główny w Księgarni Gebethnera i Wolffa, Warszawa 1903, s. 120, natomiast wielką literą w odbitce referatu wygłoszonego na I Kursie Katechetycznym we Lwowie w 1907 roku: K. Wais, O rozwoju gatunków, Drukarnia Józefa Chęcińskiego, Lwów 1907, s. 3.

${ }^{7}$ Przykładowo Wais pisze: „i t. p.” - zob. K. Wais, „Dodatek I. O początku rodu ludzkiego”, dz. cyt., s. 113; „t. j.”, tamże, s. 123.

${ }^{8}$ Ewolucyjne poglądy Waisa są tematem pracy: Z. Kępa, „Stanowisko ks. Kazimierza Waisa wobec ewolucjonizmu", Tarnowskie Studia Teologiczne, 19, z. 2, (2000), s. 275-293. Pokrótce można się z nimi zapoznać także z artykułu: P. Polak, „Neotomistyczna recepcja teorii ewolucji w Polsce w latach 1900-1939 w kontekście relacji nauka-wiara", Zagadnienia Filozoficzne w Nauce, XLIII (2008), s. 67-73.

${ }^{9}$ W „Dodatku I” do podręcznika Psychologia (1903) Wais następująco uzasadniał zabranie głosu w sprawie pochodzenia człowieka: „, [kwestię po-
} 
jak i w dyskusjach popularnych. Badania naukowe zdawały się potwierdzać biologiczną teorię ewolucji, tymczasem w obszar życia społecznego z darwinizmu przenoszona była idea konieczności walki o przetrwanie ${ }^{10}$. Darwinizm stał się również podłożem dla antyreligijnych nurtów ideologicznych takich jak monizm materialistyczny Haeckla ${ }^{11}$. Toczono także publiczne spory wokół teorii ewolucji, nierzadko obciążone światopoglądem i założeniami filozoficznymi ${ }^{12}$. Przedstawione fakty pokazują, dlaczego pisma Waisa, jak i wielu innych badaczy chrześcijańskich tamtej epoki, miały często charakter apologetyczny. Wais rzadko odnosił się bezpo-

chodzenia rodu ludzkiego] poruszamy ponieważ (...) posiada, w naszych przedewszystkiem czasach, znaczenie aktualne”. Zob. K. Wais, „Dodatek I. O początku rodu ludzkiego", dz. cyt., s. 108. Zagadnienie pochodzenia człowieka było pierwszym chronologicznie tematem ewolucyjnym, który podjął ten polski myśliciel.

${ }^{10}$ Kierunek ten nazwany został socjaldarwinizmem albo inaczej społecznym darwinizmem.

${ }^{11}$ Temat recepcji ewolucjonizmu na różnych płaszczyznach został poruszony m.in. w: J. Zon, „Ewolucjonizm”, [w:] Powszechna Encyklopedia Filozofii, t. 3, A. Maryniarczyk (red.), Polskie Towarzystwo Tomasza z Akwinu, Lublin 2002. Dostępne także online:, <http://www.ptta.pl/pef/pdf/e/ewolucjonizm.pdf>, 28.11.2010.

${ }^{12}$ Ważnym przykładem takiego sporu była sprawa Wasmanna. E. Wasmann SJ był niemieckim entomologiem, autorem podręcznika Die moderne Biologie und die Entwicklungstheorie (1904). Ze względu na wypaczone cytowanie przez Haeckla, w cyklu wykładów w 1905 roku w Berlinie, zawartych w jego książce myśli ewolucyjnych zdecydował się przedstawić swoje oryginalne poglądy w podobnym cyklu wykładów. Cykl ten odbył się w 1907 roku w Berlinie, a zakończył się - tendencyjnie ustawioną - debatą Wasmanna z niemieckimi monistami, zwolennikami Haeckla. Jednakże debata odbiła się szerokim echem w Europie i przyczyniła się do wzrostu zainteresowania kwestiami ewolucyjnymi.

Ze sprawą debaty berlińskiej można się zapoznać np. z artykułu: P. Polak, „Spór wokół teorii ewolucji przed stu laty”, Zagadnienia Filozoficzne w Nauce, XLI (2007), s. 56-90. Szczegółowa relacja została przedstawiona przez głównego polemistę debaty w książce: E. Wasmann, The Problem of Evolution: Full Report of the Lectures Given in February 190\%, and of the Evening Discussion, Kegan Paul, Trench, Trübner \& Co., London 1909. Dostępne także online: $<$ http://www.archive.org/stream/berlindiscussion00 /berlindiscussion00wasmrich.djvu >, 1.12.2011. 
średnio do tekstów Darwina, nawiązywał raczej do późniejszych publikacji traktujących o ewolucjonizmie ${ }^{13}$. Należy podkreślić, że lwowski myśliciel miał solidne, jak na ówczesne warunki, panujące na ziemiach polskich, wykształcenie filozoficzne i teologiczne, natomiast nigdy nie brał udziału w badaniach przyrodniczych, a biologię znał wyłącznie z podręczników ${ }^{14}$.

Argumenty Waisa i rozwiązania przez niego proponowane warte są zanalizowania również dlatego, że miały wpływ na wykształcenie i poglądy kolejnych pokoleń polskich neotomistów ${ }^{15}$.

\section{Pochodzenie człowieka z perspektywy ewolucjonizmu oraz opowiadania biblijnego}

Jak już zostało wspomniane, kwestia pochodzenia człowieka była poruszona przez polskiego myśliciela najwcześniej spośród zagadnień ewolucyjnych. Ma ona największe znaczenie teologiczne, gdyż w czasach Waisa nastąpiło zderzenie dwóch wizji pochodzenia człowieka - dosłownie interpretowanego opisu, przedstawionego na kartach Księgi Rodzaju i wizji materialistycznej, sprowadzającej powstanie człowieka jedynie do ślepego przypadku i procesów biologicznych.

Zagadnienie pochodzenia człowieka wiąże się także z problemem pochodzenia duszy ludzkiej, rozumianej dwojako: po pierwsze z punktu widzenia filozofii jako władza intelektualna człowieka

\footnotetext{
${ }^{13}$ Wais cytuje prace m.in. niemieckiego materialisty E. Haeckla, angielskich biologów T. Huxleya i G.J. Mivarta, krakowskiego profesora ks. F. Gabryla, neotomistów z katolickiego uniwersytetu w Louvain D. Merciera i D. Nysa, francuskiego egzegety F.G. Vigouroux, niemieckiego entomologa, jezuity E. Wasmanna.

${ }^{14}$ Por. J. Iwanicki, „Problematyka filozoficzna w ciągu ostatniego 50-lecia w Polsce", Ateneum Kapłańskie, 58 (1959), s. 258.

${ }^{15}$ Por. B. Dembowski, „Encyklika Aeterni Patris w Polsce”, [w:] Studia z dziejów myśli św. Tomasza z Akwinu, S. Swieżawski, J. Czerkawski (red.), Towarzystwo Naukowe Katolickiego Uniwersytetu Lubelskiego, Lublin 1978, s. $332-333$.
} 
lub sfera psychiczna człowieka, po drugie teologicznie - jako dusza nieśmiertelna.

\section{Odzwierzęce pochodzenie człowieka}

Kwestię pochodzenia człowieka uznawał Wais za zagadnienie z zakresu trzech dziedzin: teologii, antropologii i psychologii. Analize problemu rozpoczął stwierdzeniem, że od najdawniejszych czasów wśród wszystkich ludów przeważało przeświadczenie, iż człowiek został stworzony bezpośrednio przez Boga. Teoria zwierzęcego pochodzenia człowieka miała niewielu zwolenników do połowy XIX wieku ${ }^{16}$, kiedy to angielski biolog T. Huxley oraz szwajcarski zoolog pochodzenia niemieckiego K. Vogt ogłosili, że człowiek jest spokrewniony z małpą. Myśl tę podjął niemiecki materialista E. Haeckel, który twierdził, iż „powstał człowiek cały, z ciałem i z duszą, przez ewolucyę czysto mechaniczną"17. Według relacji Waisa, pod wpływem poglądów Haeckla, K. Darwin

\footnotetext{
${ }^{16}$ Wais podał, iż w starożytności pogląd ten wyznawał na przykład Anaksymander z Miletu, który „uczył, że ludzie żyli najpierw pod postacią ryb w wodzie i później dopiero wyszli na ląd stały, zrzuciwszy z siebie pancerne łuski”. Zob. K. Wais, „Dodatek I. O początku rodu ludzkiego”, dz. cyt., s. 108 .

Lwowski profesor pisał również, że zgodnie z jego wiedzą w nowożytności po raz pierwszy hipoteza o pochodzeniu człowieka od małpy została sformułowana pod koniec XVIII wieku przez J. Brunetta w książce O poczatku $i$ rozwoju języka. Zob. odbitka z Miesięcznika Katechetycznego $i$ Wychowawczego: K. Wais, O zwierzęcem pochodzeniu człowieka, Drukarnia Józefa Chęcińskiego, Lwów 1911, s. 3.

${ }^{17}$ K. Wais, „Dodatek I. O początku rodu ludzkiego”, dz. cyt., s. 109.

Warto już w tym miejscu zaznaczyć, że Kościół odrzuca teorię o ewolucyjnym pochodzeniu duszy ludzkiej, a także takie teorie jak panteizm emanacyjny (pogląd głoszący, że dusza jest wynikiem emanacji bóstwa), reinkarnację (teorię, że po śmierci ciała dusza może ponownie wcielić się w inne ciało), tradukcjonizm (pogląd mówiący dusza jest przekazywana dziecku przez rodziców). Pozytywnie stwierdza natomiast, że Bóg stwarza bezpośrednio każdą duszę ludzką. Zob. Pius XII, encyklika Humani Generis. O błędach przeciwnych Wierze katolickiej (12 VIII 1950), Te Deum, Warszawa 2002, s. 24 .
} 
w książce $O$ pochodzeniu człowieka (1871) napisał, iż człowiek pochodzi od zwierzęcia i różni się od niego wyłącznie pod względem stopnia, innymi słowy ilościowym, a nie istotnym, czyli jakościowym.

Wais nie zgadzał się z powyższym stanowiskiem naturalistycznym. Twierdził, że „umysł filozoficzny, rozważając rzecz gruntownie, dochodzi do przekonania, że człowiek różni się istotnie od zwierzęcia" ${ }^{18}$. Polski myśliciel widział zatem, dostrzegalną rozumowo, różnicę w istocie, czyli w formie substancjalnej, zwierząt i człowieka. Różnica ta jest ontologiczna i niemożliwa do pokonania. Jednocześnie K. Wais nie przeczył istnieniu pewnych podobieństw między człowiekiem i zwierzęciem - jak na przykład posiadanie zmysłów, pamięci, wyobraźni, instynktów. Tym, co zdaniem Waisa, odróżnia człowieka od zwierzęcia, jest rozum jest to rozwiązanie zaproponowane przez Arystotelesa, który intelektualną władzę duszy przypisywał jedynie człowiekowi. Według Waisa, dzięki rozumowi „tworzymy pojęcia ogólne i oderwane, poznajemy istotę rzeczy i byty niemateryalne (...), poznajemy Boga, prawdę, dobro, piękno, cnotę, sprawiedliwość itp." 19 . O braku rozumu u zwierząt autor Kosmologii szczególowej wnioskował na podstawie braku skutków jego używania - argumentowal, że gdyby zwierzęta posiadały rozum, wykształciłyby mowę, byłyby zdolne do samodoskonalenia się, poznawałyby Bóstwo oraz dobro i zło moralne, a zatem wykształciłyby religię i moralność, znałyby związki przyczynowo-skutkowe swoich działań ${ }^{20}$. Rozumowaniu Waisa można tu zarzucić nieuprawomocniony przeskok od obserwacji zachowań do rozstrzygnięć metafizycznych ${ }^{21}$.

\footnotetext{
${ }^{18} \mathrm{~K}$. Wais, O zwierzęcem pochodzeniu człowieka, dz. cyt., s. 8.

${ }^{19}$ K. Wais, „Dodatek I. O początku rodu ludzkiego”, dz. cyt., s. 113.

${ }^{20}$ Por. K. Wais, „Czy zwierzęta mają rozum?”, Przeglad Filozoficzny, 1907, R. 10, z. 4, s. 509. Dostępne także online: <http://www.wbc.poznan.pl/dlibra/ docmetadata?id=\&from $=$ publication $>$, 18.11.2011.

${ }^{21} \mathrm{~W}$ Przegladzie Filozoficznym w krótkiej notatce pod tekstem referatu Waisa „Czy zwierzęta mają rozum?” (1907) napisano, że wykład ten wywołał ożywioną dyskusję, w której uczestniczyli m.in. J. Kurnatowski, ks. J. Nuckowski, prof. K. Twardowski i dr W. Witwicki. Referującemu zarzucono
} 
K. Wais podkreślał za Arystotelesem, że dusza jest podstawą władz i objawów psychicznych, więc między duszą ludzką a zwierzęcą istnieje istotna, ontologiczna różnica. Dusza ludzka jest przede wszystkim rozumna i duchowa, zwierzęca natomiast zmysłowa i zależna bezpośrednio od ciała ${ }^{22}$. Niemożliwe jest przekształcenie się duszy zwierzęcej w duszę ludzką, gdyż byłoby to sprzeczne z zasadą przyczynowości. Wais pisał:

Aby przejść od pierwszej do drugiej, nie wystarczy rozwinąć i udoskonalić to, co już istnieje, ale należy stworzyć coś, czego całkiem niema. Że zaś akt stwórczy, czyli wyprowadzenie czegoś z nicości, przysługuje wyłącznie Bogu, przeto On tylko mógł stworzyć pierwszą duszę ludzką, jak stworzył i stwarza wszystkie późniejsze ${ }^{23}$.

Wyjaśnienie problemu powstawania duszy ludzkiej poprzez akt stwórczy Boga jest typowe dla teologii i filozofii chrześcijańskiej, należy jednak zwrócić uwage na to, że Wais w uzasadnieniu odwoływał się nie do wiary, ale do arystotelesowskiego podziału na trzy władze duszy.

Lwowski profesor pisał również, iż pod względem anatomicznym nie można zaliczyć człowieka do żadnej podkategorii systematycznej królestwa zwierząt. Jego zdaniem ludzie stanowią osobny ród, innymi słowy oddzielne królestwo. Na potwierdzenie swojej tezy podał Wais kilka ważniejszych różnic anatomicznych pomiędzy człowiekiem i małpą, między innymi w budowie kończyn górnych i dolnych, miednicy oraz czaszki ${ }^{24}$.

głównie, że brak pojęcia Bóstwa u zwierząt nie implikuje braku rozumu, gdyż mogą istnieć także ludzie, którzy nie posiadają tego pojęcia; polemiści uznali, iż lepszym argumentem na brak rozumu u zwierząt byłoby wykazanie, że nie mają one w ogóle pojęć abstrakcyjnych. Zob. anonimowa notatka pod streszczeniem referatu K. Waisa „Czy zwierzęta mają rozum?”, dz. cyt., s. 510 .

${ }^{22}$ Zob. K. Wais, O zwierzęcem pochodzeniu czlowieka, dz. cyt., s. 8-9.

${ }^{23}$ Zob. tamże, s. 13.

${ }^{24}$ Różnice te są szczegółowo omówione w: K. Wais, „Dodatek I. O początku rodu ludzkiego", dz. cyt., s. 116-119; K. Wais, O zwierzęcem pochodzeniu człowieka, dz. cyt., s. 19-21. 
Wais przedstawił także dwa typy argumentów, którymi posługują się zwolennicy teorii o ewolucyjnym pochodzeniu człowieka, opatrując je krytycznym komentarzem.

Pierwszy argument, pochodzący od Darwina, nazwał K. Wais „ogólnym dowodem" i przytoczył w następującym brzmieniu: „rzeczy, podobne do siebie, mają wspólne pochodzenie; człowiek jest podobny do zwierzęcia: więc od niego pochodzi” ${ }^{25}$. Lwowski neotomista uzasadnił, że obydwie części powyższego rozumowania są niepoprawne: pierwsza - gdyż nie została udowodniona oraz można wskazać przykłady, które ją podważają; druga - gdyż mimo pewnego podobieństwa pomiędzy człowiekiem a zwierzęciem, jest między nimi różnica istotna. Wais słusznie krytykował zbyt szybkie wnioskowanie o pochodzeniu na podstawie podobieństwa, jednak jego uzasadnienie obarczone jest założeniami, dotyczącymi istnienia istotowej różnicy między człowiekiem a zwierzęciem, typowymi dla filozofii tomistycznej.

Drugi typ argumentów ewolucjonistów stanowiły według K. Waisa „dowody drugorzędne”. Wais pisał, iż „należą do nich: stan umysłowy ludzi przedhistorycznych, stan dzisiejszych plemion dzikich i dzieci, rozwój embryonu, narządy cząstkowe i zjawiska atawizmu" 26 . Dowody te miały ukazywać podobieństwo rozwoju człowieka do rozwoju zwierzęcia. Polski filozof rozprawiał się z wszystkimi wyżej wymienionymi argumentami. Twierdzil, że pod względem intelektualnym różnica między człowiekiem pierwotnym a cywilizowanym jest jedynie ilościowa, ponieważ już człowiek dziki charakteryzował się rozumem - wykształcił mowę, normy religijne i etyczne, potrafil zdobywać wiedzę. Dziecko, zdaniem Waisa, różni się od zwierzęcia tym, że „w chwili, w której otrzymuje duszę, otrzymuje zdolność do myślenia, czyli władzę rozumu" 27 , która jest pewną potencjalnością i ujawnia się dopiero wraz z rozwojem wyobraźni, dającej rozumowi materiał do myślenia. W kwestii embrionu ludzkiego K. Wais pisał, że „zarodek

\footnotetext{
${ }^{25}$ K. Wais, „Dodatek I. O początku rodu ludzkiego”, dz. cyt., s. 123.

${ }^{26}$ Tamże, s. 123.

${ }^{27}$ Tamże, s. 124 .
} 
nasz zbliża się w ciągu swego rozwoju jedynie do niektórych form zwierzęcych i to powierzchownie, i pod pewnymi względami" ${ }^{28}$, zatem podobieństwo embrionu ludzkiego i zwierzęcego jest jedynie pozorne; ponadto Wais dodał, iż z embrionu ludzkiego może powstać tylko człowiek, a ze zwierzęcego wyłącznie zwierzę - decyduje o tym ich forma substancjalna, która nie może ulec zmianie. Istnienie narządów szczątkowych, zdaniem lwowskiego profesora, nie musi być wyrazem zwierzęcego pochodzenia człowieka, gdyż „można przypuścić, że narządy rzeczone świadczą o jednolitym planie, którego się trzymał Stwórca [...]. Bóg zmienia go tylko w szczegółach, powołując w ten sposób przy mądrej oszczędności środków, najrozmaitsze stworzenia do bytu" ${ }^{29}$ - Wais był świadomy, że nauka w jego czasach nie potrafi udzielić odpowiedzi na pytanie o rolę narządów szczątkowych i stawia hipotezę, która według niego daje proste wytłumaczenie tego problemu. Jeśli chodzi o atawizm, Wais twierdził, że podawany przez darwinistów przykład mikrocefalów, czyli ludzi charakteryzujących się bardzo małą czaszką i mózgiem, prowadzących niemal zwierzęce życie, nie jest objawem atawizmu, lecz stanem patologicznym organizmu ludzkiego.

Argumentów za ewolucyjnym pochodzeniem człowieka dostarcza także paleontologia. Wais omawiał kwestię szczątków kopalnych uchodzących za formy przejściowe między małpami a człowiekiem. Uważał między innymi, że znalezienie w 1894 roku na wyspie Jawie kilku kości przedstawiciela gatunku Pithecanthropus erectus ${ }^{30}$, nie potwierdza odzwierzęcego pochodzenia człowieka. Lwowski filozof powoływał się na rozbieżność opinii bio-

${ }^{28}$ Tamże, s. 125 .

${ }^{29}$ Tamże, s. $126-127$.

${ }^{30}$ Nazwa Pithecanthropus erectus pochodzi od gr. pithekos - małpa, anthropos - człowiek. Wais używał również terminów: małpolud, małpoczłek wyprostowany. Zob. K. Wais, O zwierzęcem pochodzeniu człowieka, dz. cyt., s. 35-36, por. także: K. Wais, O rozwoju gatunków, dz. cyt., s. 27.

Współcześnie ten gatunek nazywany jest Homo erectus. Zob. E. Haduch, „Homo erectus”, [w:] Wielka Encyklopedia PWN, t. 11, J. Wojnowski (red.), Wydawnictwo Naukowe PWN, Warszawa 2002. 
logów - jedni podważali wyprostowaną postawę tej istoty żywej, inni wzbraniali się przed wydawaniem jakiegokolwiek werdyktu dotyczącego przynależności systematycznej Pithecanthropusa erectusa, zanim nie zostanie odnaleziony cały szkielet. Ponadto wedle relacji Waisa, z badań warstw geologicznych, w których leżały kości, wynikało, że w okresie, gdy żył Pithecanthropus erectus, był już na ziemi człowiek.

Rozumowanie Waisa w tym miejscu polegało wyłącznie na odpieraniu argumentów zwolenników hipotezy o ewolucyjnym powstaniu człowieka, miało więc charakter negatywny. Stosując tę metodę Wais wnioskował, że ludzie i zwierzęta stanowią różne kategorie systematyczne. W naukach biologicznych takie rozumowanie nie jest uprawnione, gdyż wykazanie, że argumenty mające potwierdzić pewną tezę są niepoprawne, nie dowodzi prawdziwości żadnej innej tezy.

\section{Utworzenie człowieka przez Boga „,z mułu ziemi”}

Stwierdziwszy odrębność systematyczną ludzi i zwierząt, Wais rozważał kwestię, skąd wziął się pierwszy człowiek - próbował zatem zbudować koncepcję pozytywną. Skoro nauki przyrodnicze nie dawały odpowiedzi na to pytanie ${ }^{31}$, ksiądz profesor odniósł się do teologii. Przytoczył werset Rdz 2,7: „Utworzył tedy Pan Bóg człowieka z mułu (prochu) ziemi i natchnął w oblicze jego dech żywota" ${ }^{32}$, ponadto dopowiedział, że dzięki rozumowi człowiek poznaje, iż powyższe słowa odnoszą się także do ludzkiej duszy. Wais odwoływał się więc do rozumu jako sfery, dzięki której człowiek wie, że dusze ludzkie są dziełem Boskim - jest to teza

${ }^{31}$ Wais twierdził, iż „nauka nie posiada rzeczywiście ani jednego dowodu na to, że ciało nasze powstało ze zwierzęcego". K. Wais, O rozwoju gatunków, dz. cyt., s. 28.

${ }^{32}$ K. Wais, „Dodatek I. O początku rodu ludzkiego”, dz. cyt., s. 119.

W Biblii Tysiaclecia werset ten brzmi: „wtedy to Pan Bóg ulepił człowieka z prochu ziemi i tchnął w jego nozdrza tchnienie życia, wskutek czego stał się człowiek istota żywą". 
filozoficzna, zaczerpnięta ze scholastyki. Współcześnie Kościół naucza, jak to zostało potwierdzone w encyklice Piusa XII Humani Generis (1950), iż to, że dusze zostały stworzone przez Boga, poznaje człowiek przez wiarę ${ }^{33}$.

Wais uważał, że słów o utworzeniu czy ulepieniu ciała pierwszego człowieka przez Boga nie należy wyobrażać sobie literalnie, gdyż byłoby to sprzeczne z czysto duchową istotą Stwórcy ${ }^{34}$. Fragment ten zdaniem Waisa „zaznacza tylko, że Bóg sam uczynił ciało Adama z materyi na początku stworzonej, czyli z pierwiastków znajdujących się na ziemi" ${ }^{35}$. Zatem człowiek w swej istocie został utworzony wyłącznie przez Boga, bez żadnych innych przyczyn zewnętrznych.

Wais zastanawiał się natomiast, jak należy interpretować akt stwórczy w kontekście opisu z Rdz 2,7 i czy można dopuścić ewolucję ciała ludzkiego. Wprowadził rozróżnienie między faktem stworzenia a możliwością ewolucyjnego powstania ciała człowieka.

Odnosząc się do kwestii faktu stworzenia, Wais podawał, że większość jemu współczesnych teologów i filozofów katolickich uważała, że zarówno ciało jak i dusza ludzka zostały stworzone bezpośrednio przez Boga. Pisał, że istnieją także myśliciele katoliccy, z G.J. Mivartem na czele, którzy będąc zwolennikami ewolucjonizmu, uznawali odzwierzęce pochodzenie człowieka co do ciała:

Ciało tedy Adama - powiadają darwiniści katoliccy - było wprawdzie dziełem Bożem, ale pośrednio, tj. przez prawa natury czyli ewolucyę: onato zapomocą kolejnych transformacyj, które odbywały się w zwierzętach, przygotowywała

33 „,...] że bowiem dusze stwarzane są bezpośrednio przez Boga, tego niewątpliwie uczy nas katolicka wiara". Pius XII, encyklika Humani Generis. O błędach przeciwnych Wierze katolickiej (12 VIII 1950), dz. cyt., s. 24.

${ }^{34}$ Ks. prof. T. Brzegowy pisze, iż już św. Augustyn twierdził, że werset ten należy rozumieć przenośnie, gdyż Bóg nie ma rąk, którymi mógłby lepić. Zob. T. Brzegowy, Pięcioksiag Mojżesza. Wprowadzenie i egzegeza Ksiegi Rodzaju 1-11, Biblos, Tarnów 2002, s. 275.

${ }^{35} \mathrm{~K}$. Wais, O zwierzęcem pochodzeniu człowieka, dz. cyt., s. 45. 
i udoskonalała „muł ziemi” tak długo, aż Stwórca mógł go połączyć z duszą ludzką ${ }^{36}$.

Wais zaznaczył, że badacze byli i są świadomi, iż ewolucyjne pochodzenie człowieka jest hipotezą, której nie da się udowodnić, a którą jedynie uprawdopodabnia pewne podobieństwo między zwierzętami a ludźmi.

W duchu tomizmu Wais uważał, że nie ma możliwości, aby forma bardziej doskonała sama z sobie powstała z formy mniej doskonałej - każda z nich ma inną istotę, która nie ulega zmianom. Zatem mechaniczne i nie zakładające celowości rozumienie ewolucji należy, zdaniem Waisa, odrzucić. Jednakże człowiek niekoniecznie musiał powstać bezpośrednio i natychmiastowo z materii martwej; ingerencja Boga mogła bowiem sprawić, że poprzez czynniki naturalne wykształciło się „ciało, jakiego wymaga dusza rozumna" 37 .

Wais podzielał jednak pogląd ówcześnie bardziej powszechny. Nie widział powodu, aby rezygnować $\mathrm{z}$ dosłownego rozumienia $\operatorname{Rdz} 2,7$, gdyż jego zdaniem

wszystko raczej za takiem tłumaczeniem przemawia; i sam tekst w sobie jasny i inne miejsca równoległe (Ekkli., 17,1; tamże, 33,10; Ekkle., 12,7; 1 Kor., 15,47) ${ }^{38}$ i bezpośrednie utworzenie ciała Ewy z żebra Adama ${ }^{39}$.

\footnotetext{
${ }^{36}$ K. Wais, „Dodatek I. O początku rodu ludzkiego”, dz. cyt., s. 120.

${ }^{37}$ Tamże, s. 123.

${ }^{38} \mathrm{~W}$ tłumaczeniu Biblii Tysiaclecia wspominane przez Waisa wersety brzmią: „Pan stworzył człowieka z ziemi i znów go jej zwróci” (Syr 17,1); „Wszyscy ludzie są z mułu, i z ziemi Adam został stworzony” (Syr 33,10); „i wróci się proch do ziemi, tak jak nią był, a duch powróci do Boga, który go dał” (Koh 12,7); „Pierwszy człowiek z ziemi - ziemski, drugi Człowiek z nieba" (1 Kor 15,47).

${ }^{39}$ K. Wais, „Dodatek I. O początku rodu ludzkiego”, dz. cyt., s. 120-121. Dodatkowo w przypisie Wais podał, że nawet katoliccy ewolucjoniści uznawali bezpośrednie stworzenie ciała pierwszej niewiasty.

Obecnie w teologii uznaje się, że opis stworzenia Ewy ma znaczenie symboliczne. Jest świadectwem identyczności natury dwóch płci i ich komplementarności, stanowi również pouczenie o godności kobiety. Zob. T. Brzegowy,
} 
Wais literalnie odczytywał wszystkie powyżej wymienione fragmenty Pisma Świętego. Podkreślał także różnicę pomiędzy biblijnym opisem powstania człowieka a opisem powołania do życia roślin i zwierząt: w przypadku człowieka stało się to za sprawą bezpośredniego działania Boga; natomiast „rośliny i zwierzęta wydaje z siebie ziemia lub woda tylko na Jego wszechmogacy rozkaz" 40 .

Ponadto lwowski myśliciel uważał, że tam, gdzie dopuszczalne są różne interpretacje Pisma Świętego, należy wybierać możliwie najmniej skomplikowane wytłumaczenie ${ }^{41}$. Według Waisa nie ma zatem argumentów, które uprawniałyby rozszerzenie teorii ewolucji, nieudowodnionej jego zdaniem nawet w kwestii pochodzenia zwierząt, na człowieka.

K. Wais podkreślał, że Magisterium Kościoła nie wydało żadnego wiążącego katolików orzeczenia w sprawie pochodzenia człowieka. Zarazem zaznaczał, iż hipoteza o odzwierzęcym pochodzeniu ciała ludzkiego nie stoi w sprzeczności ze stworzeniem człowieka przez Boga „z mułu ziemi” - dokonałoby się to na sposób pośredni. Jeśli miałby to być proces ewolucyjny, to na podstawie pism Waisa można się domyślić, że forma życia, z której wykształciła się istota ludzka, musiałaby zawierać w sobie daną przez Stwórce potencjalność do bycia człowiekiem. Byłoby to rozstrzygnięcie podobne do tego, jakie autor Kosmologii szczegółowej proponuje w kwestii powstania życia ${ }^{42}$.

Jednocześnie Wais pisał, iż

Pięcioksiag Mojżesza. Wprowadzenie i egzegeza Księgi Rodzaju 1-11, dz. cyt., s. $287-288$.

${ }^{40} \mathrm{~K}$. Wais, O zwierzęcem pochodzeniu człowieka, dz. cyt., s. 45.

${ }^{41}$ Ks. Z. Kępa zauważa, że po przedstawieniu racji teologicznych, Wais powołał się na argument metodologiczny, który stanowił w opinii lwowskiego profesora „wzgląd czysto naukowy”. Zob. Z. Kępa, „Stanowisko ks. Kazimierza Waisa wobec ewolucjonizmu", dz. cyt., s. 281.

${ }^{42}$ Warto w tym miejscu jeszcze raz podkreślić - na co zwraca również uwagę ks. Z. Kępa - że w przeciwieństwie do stworzenia człowieka przez Boga, ewolucyjne pochodzenie ciała ludzkiego było dla Waisa tylko „kwestią możliwości”, nie „kwestią faktu”. Por. Z. Kępa, „Stanowisko ks. Kazimierza Waisa wobec ewolucjonizmu", dz. cyt., s. 282. 
[nauki przyrodnicze] nie wykażą nigdy, że dusza ${ }^{43}$ ludzka wyłoniła się ze zwierzęcej, bo to przekracza zakres ich badania, a psychologia racyonalna, do której zagadnienie o początku duszy należy, wykazuje (...) niewątpliwie, iż duch $^{44}$ nasz nie mógł mieć początku zwierzęcego, ale powstał poprzez bezpośredni czyn stwórczy ${ }^{45}$.

Wais wskazywał, że pojęcie duszy leży poza granicami biologii, natomiast jest, według niego, dostępne badaniu rozumowemu. O ile z pierwszą częścią cytowanego stwierdzenia należy się zgodzić,

${ }^{43}$ Duszę Wais definiował jako „to, przez co ciało żyje (...), wewnętrzną podstawę życia w bytach organicznych". Jest to arystotelesowska koncepcja duszy rozumnej (w odróżnieniu od duszy roślinnej i zwierzęcej, o których Wais pisał, że są przeważnie nazywane pierwiastkiem życiowym). Dusza jest substancją niezupełną (substancia incompleta), tj. z natury przeznaczoną do połączenia się z ciałem w jedną substancjalną całość. Jest substancją niezłożoną, jest niematerialna, czyli duchowa i stąd wynika jej nieśmiertelność. Dusza jest formą substancjalną ciała. Zob. K. Wais, „Dusza”, [w:] Podręczna Encyklopedya Kościelna, t. 9-10, S. Gall, J. Niedzielski i inni (oprac.), Skład główny w Księgarni Gebethnera i Wolffa, Warszawa 1906. Dostępne także online: <http://www.wbc.poznan.pl/publication/86255>, 22.11.2011

Warte podkreślenia jest to, że na początku definicji duszy Wais charakteryzował ją na sposób arystotelesowsko-tomistyczny (analogicznie do klasycznej definicji, iż „dusza to pierwszy akt ciała naturalnego mający w możności życie"), a potem zawęził to pojęcie do duszy rozumnej (ludzkiej).

${ }^{44}$ Duch to „substancya samoistna, to jest niezależna od ciała w istnieniu i działaniu, a posiadająca rozum i wolną wolę". Duch może połączyć się z ciałem w jedną naturę, tworząc duszę ludzką. Zob. K. Wais, „Duch”, [w:] Podręczna Encyklopedya Kościelna, dz. cyt.

Duch jest zatem przyczyną powstania duszy, jest czymś pierwotnym względem duszy.

Definicje duszy i ducha autorstwa Waisa zostały tutaj przytoczone, aby ukazać, że w podanym fragmencie nie myli on pojęć ducha i duszy; stosuje te terminy świadomie, ale w rozumieniu cytowanych definicji.

Warto także podkreślić, że przy formowaniu tych definicji Wais nie podążał konsekwentnie za myśleniem arystotelesowsko-tomistycznym, lecz dodał spojrzenie teologiczne i pojęciu ducha nadał cechy platońskie.

${ }^{45} \mathrm{~K}$. Wais, O zwierzęcem pochodzeniu człowieka, dz. cyt., s. $45-46$. 
o tyle druga jest nieuzasadniona - filozofia ${ }^{46}$ nie może podać dowodu na stworzenie duszy przez Boga, może to być co najwyżej jej założenie aprioryczne. Stworzenie duszy bezpośrednio przez Boga jest kwestia wiary, co zostało potwierdzone w encyklice Piusa XII Humani Generis (1950) ${ }^{47}$.

Warto także dodać, iż współcześnie w egzegezie uznaje się, że werset Rdz 2,7 nie podaje precyzyjnego opisu stworzenia człowieka, ma na celu przekazanie prawdy teologicznej, iż „człowiek we wszystkim, z czego się składa, jest zależny od Boga" 48 .

\section{Zakończenie}

Proponowane przez Waisa rozwiązanie kwestii pochodzenia człowieka było efektem prób harmonizowania ewolucjonizmu i nauki Kościoła w oparciu o filozofię neotomistyczną. Jest ważnym głosem w historii relacji nauka-wiara - Wais jako jeden z pierwszych polskich myślicieli rozważa możliwość ewolucyjnego pochodzenia ciała człowieka, podaje argumenty, świadczące, jego zdaniem, o odrębności systematycznej ludzi i zwierząt, zastanawia się, jak w kontekście ówczesnego stanu nauki interpretować biblijny opis stworzenia człowieka, zwraca uwage na problem pochodzenia duszy ludzkiej.

Trzeba przyznać, że Wais był dobrym filozofem-systematykiem, co podkreśla ks. J. Stepa, pisząc:

prawdzie nie wskazał filozofii katolickiej nowych dróg [...], lecz zebrał skrzętnie to wszystko, co przekazała nam wielka tradycja średniowieczna i umiejętnie złożył w oryginalną

${ }^{46} \mathrm{~W}$ czasach Waisa psychologia racjonalna była częścią filozofii. Zob. np. A. Wyczółkowska, „O obecnej kryzys w psychologii (Dokończenie)”, Życie, 1897, R. 1, Nr 13 (18 XII), s. 4.

${ }^{47}$ Zob. Pius XII, encyklika Humani Generis. O blędach przeciwnych Wierze katolickiej (12 VIII 1950), dz. cyt., s. 24.

${ }^{48}$ T. Brzegowy, Pięcioksiag Mojżesza. Wprowadzenie i egzegeza Ksiegi Rodzaju 1-11, dz. cyt., s. 275. 
całość. Okazał przy tem dużą zdolność do analizy, choć mniejszą do syntezy ${ }^{49}$.

Prace Waisa charakteryzują się przejrzystością, argumenty bywaja zorganizowane w punktach, autor Kosmologii szczegółowej konsekwentnie prowadził swoje wywody ${ }^{50}$, chociaż czasem wyciągał nieuprawomocnione wnioski. Lwowski profesor wykazywał się erudycją, cytował wielu autorów, także w językach łacińskim, angielskim, francuskim, niemieckim.

Z dzisiejszej perspektywy stanowisko Waisa w sprawie pochodzenia człowieka jest zaskakujące. Polski neotomista dopuszczał ewolucję w przypadku zwierząt, argumentując, że stworzenie świata wyposażonego w zdolność ewolucyjnego przekształcania się ukazuje mądrość Stwórcy; uznawał jednak, że człowiek został stworzony przez Boga bezpośrednio. Rozbieżność ta nie została przez Waisa w pełni uzasadniona, miała ona źródło w arystotelesowskotomistycznej koncepcji istnienia wyłącznie u człowieka intelektualnej władzy duszy. Należałoby więc ostrożnie podchodzić do apriorycznych założeń tomizmu, jak i każdego innego systemu filozoficznego, gdyż nie są one weryfikowalne, a wpływają na późniejsze rozstrzygnięcia.

W pismach Waisa wyraźny jest ponadto aspekt apologetyczny. Niektóre wątki sprawiają wrażenie, iż neotomizm daje narzędzia do obrony Pisma Świętego przed wpływem wrogich chrześcijaństwu filozofii jak na przykład materializm Haeckla.

Prace K. Waisa są cennym świadectwem historycznym zmagań katolickiego filozofa i teologa z kwestiami ewolucyjnymi i stanowią ważną pod względem historycznym próbę wypracowania rozwiązań ukazujących niesprzeczność nauki i wiary.

${ }^{49}$ J. Stepa, „Śp. ks. Kazimierz Wais jako filozof”, [w:] A. Gerstmann, S. Momidłowski, J. Stepa, Życie $i$ działalność śp. ks. Kazimierza Waisa, dz. cyt., s. 21.

${ }^{50} \mathrm{Na}$ walory pedagogiczne dzieł Waisa wskazuje również ks. Stepa w artykule „Ks. Kazimierz Wais (1865-1934)”, dz. cyt., s. 305. 


\section{Bibliografia}

1. Brzegowy T., Pięcioksiag Mojżesza. Wprowadzenie i egzegeza Ksiegi Rodzaju 1-11, Biblos, Tarnów 2002.

2. Dembowski B., „Encyklika Aeterni Patris w Polsce”, [w:] Studia z dziejów myśli św. Tomasza z Akwinu, Swieżawski S., Czerkawski J. (red.), Towarzystwo Naukowe Katolickiego Uniwersytetu Lubelskiego, Lublin 1978, s. 315-334.

3. Gerstmann A., Momidłowski S., Stepa J., „Życie i działalność śp. ks. Kazimierza Waisa", Collectanea Theologica, 16 (1935), z. 1, s. 1-21.

4. Gretka W., „Wais Kazimierz”, [w:] Powszechna Encyklopedia Filozofi, t. 9, A. Maryniarczyk (red.), Polskie Towarzystwo Tomasza z Akwinu, Lublin 2008. Dostępne także online: $<$ http://www.ptta.pl/pef/pdf/w/wais_k.pdf $>, 25.10 .2010$,

5. Haduch E., „Homo erectus”, [w:] Wielka Encyklopedia PWN, t. 11, J. Wojnowski (red.), Wydawnictwo Naukowe PWN, Warszawa 2002.

6. Iwanicki J., „Problematyka filozoficzna w ciągu ostatniego 50-lecia w Polsce", Ateneum Kapłańskie, 58 (1959), s. $255-293$.

7. Kępa Z., „Stanowisko ks. Kazimierza Waisa wobec ewolucjonizmu", Tarnowskie Studia Teologiczne, 19 (2000), z. 2, s. $275-293$.

8. Leon XIII, encyklika Aeterni Patris. O filozofii chrześcijańskiej (4 VII 1879), Te Deum, Warszawa 2003.

9. Majka J., Metodologia nauk teologicznych, wyd. Wrocławskiej Księgarni Archidiecezjalnej, Wrocław 1981. 
10. Nagy S., „Apologetyka polska”, [w:] Dzieje teologii katolickiej w Polsce, t. 3, cz. 1, Lublin 1976, s. 183-217.

11. Pius XII, encyklika Humani Generis. O btędach przeciwnych Wierze katolickiej (12 VIII 1950), Te Deum, Warszawa 2002.

12. Polak P., „Spór wokół teorii ewolucji przed stu laty”, $Z a$ gadnienia Filozoficzne w Nauce, XLI (2007), s. 56-90.

13. Polak P., „Neotomistyczna recepcja teorii ewolucji w Polsce w latach 1900-1939 w kontekście relacji nauka-wiara", Zagadnienia Filozoficzne w Nauce, XLIII (2008), s. 44-88.

14. Stepa J., „Ks. Kazimierz Wais (1865-1934)”, Przeglad Filozoficzny, 37, z. 3 (1934), s. 303-306.

15. Vorgrimler H., Nowy leksykon teologiczny, Verbinum, Warszawa 2005.

16. Wasmann E., The Problem of Evolution: Full Report of the Lectures Given in February 1907, and of the Evening Discussion, Kegan Paul, Trench, Trübner \& Co., London 1909. Dostępne także online:, <http://www.archive.org/stream/berlindiscussion00 /berlindiscussion00wasmrich.djvu>, 1.12.2011.

17. Wais K., „Dodatek I. O początku rodu ludzkiego”, [w:] Psychologia, t. IV, Skład główny w Księgarni Gebethnera i Wolffa, Warszawa 1903, s. 108-155.

18. Wais K., „Duch”, [w:] Podręczna Encyklopedya Kościelna, t. 9-10, S. Gall, J. Niedzielski i inni (oprac.), Skład główny w Księgarni Gebethnera i Wolffa, Warszawa 1906. Dostępne także online: $<$ http://www.wbc.poznan.pl/publication/86255>, 22.11.2011.

19. Wais K., „Dusza”, [w:] Podręczna Encyklopedya Kościelna, t. 9-10, S. Gall, J. Niedzielski i inni 
(oprac.), Skład główny w Księgarni Gebethnera i Wolffa, Warszawa 1906. Dostępne także online: <http://www.wbc.poznan.pl/publication/86255>, 22.11.2011.

20. Wais K., „Czy zwierzęta mają rozum?”, Przeglad Filozoficzny, 1907, R. 10, z. 4, s. 508-510. Dostępne także online: <http://www.wbc.poznan.pl/dlibra/docmetadata?

$=119419 \&$ from $=$ publication $>, 18.11 .2011$.

21. Wais K., „O rozwoju gatunków”, Gazeta Kościelna, 1907, R. 15 , nr 13, s. $133-135$; nr 14, s. 145-147; nr 16, s. $165-167 ;$ nr 17 , s. $174-176$. Dostępne także jako odbitka: K. Wais, O rozwoju gatunków, Drukarnia Józefa Chęcińskiego, Lwów 1907. Dostępne również online: <http://www.sbc.org.pl/dlibra/doccontent?id $=19538 \&$ from $=$ FBC $>, 18.11 .2011$.

22. Wais K., „O zwierzęcem pochodzeniu człowieka”, Miesięcznik Katechetyczny i Wychowawczy, 1911, R. 1, z. 1, s. 15-23; z. 2 , s. $58-68$; z. 3, s. 105-118; z. 4, s. 149-162. Dostępne także jako odbitka: K. Wais, $O$ zwierzęcem pochodzeniu człowieka, Drukarnia Józefa Chęcińskiego, Lwów 1911.

23. Wais K., Kosmologia szczegółowa, cz. I, nakładem „Studia Gnesnesia", Gniezno 1931.

24. Wołczański J., „Życiorys i bibliografia opublikowanych prac ks. prof. dra Kazimierza Waisa za lata 1895-1932", Roczniki Filozoficzne, t. XXXI, z. 1 (1983), s. 133-145.

25. Wyczółkowska A., „O obecnej kryzys w psychologii (Dokończenie)", Życie, 1897, R. 1, Nr 13 (18 XII), s. 3-5. Dostępne także online: <http://mbc.malopolska.pl/dlibra/doccontent $? \mathrm{id}=9085 \&$ dirids $=1>, 18.11 .2011$.

26. Zon J., „Ewolucjonizm”, [w:] Powszechna Encyklopedia Filozofi, t. 3, A. Maryniarczyk (red.), Polskie Towarzy- 
stwo Tomasza z Akwinu, Lublin 2002. Dostępne także online: <http://www.ptta.pl/pef/pdf/e/ewolucjonizm.pdf >, 28.11.2010.

27. Pismo Święte Starego i Nowego Testamentu w przektadzie z języków oryginalnych opracowat zespót biblistów polskich $z$ inicjatywy Benedyktynów Tynieckich (Biblia Tysiaclecia), wyd. IV, Pallottinum, Poznań 1991.

\section{Abstract}

\section{Professor Kazimierz Wais' proposition of harmoni- zing science and faith regarding the origin of man}

This paper is aimed to present Kazimierz Wais' considerations on the concept of the origin of man. Kazimierz Wais (1865-1934) was a Polish philosopher and theologian, a professor at the University of L'viv. In his publications, Wais criticized the purely naturalistic theory of the origin of man and presented a positive theory not inconsistent with the Biblical description; he also commented on the issue of the origin of human soul. His views were strongly affected by neo-Thomistic philosophy. The paper shows Wais' attempts to prove the harmony of science and faith regarding the origin of man. His reflections are presented and critically commented.

Keywords: Kazimierz Wais, evolutionism, neo-Thomism, origin of man, relationship between science and faith. 